\title{
Author/Title Index to volume 10 (1990)
}

(Numbers appearing within parentheses before the page numbers indicate the issue in which an item was published.)

Bakkes, J.A., Outline of a potential environment and health metadatabase for the Netherlands

Behling, G. and M. Matthies, Development of a metadatabase on environmental monitoring programmes

Berg Hansen, I., Expert systems as tools for integration and analysis of environmental health information

Boni, M., F. Geiss and W. Penning, The ECDIN database for chemicals in the environment

Briggs, D.J., Establishing an environmental information system for the European Community: the experience of the CORINE Programme

Burke, M.A., Implications of microcomputer availability for information seeking behaviour

Cawkell, A.E., Editorial: The annual "arrival" of speech recognition

Coyne, J.G. and W.M. Vaden, A Single Europe: Will it impact existing information exchanges between U.S. and European governments?

Coalgate, B.: see Ryan, R.P.

Cuadra, C.A., Better text management

Cuadra, C.A., STAR ${ }^{\circledR}$ : History, development and use

(3) $133-134$

(6) $341-350$

(6) $371-379$

(5) $305-313$

(6) $381-390$

Dou, H., P. Hassanaly, A. La Tela and L. Quoniam, Advanced interfaces to analyse automatically online database set of answers

Elias, A.W., Editorial: The worlds of information

(5) $259-260$

Elliott, P., Small area health statistics in Europe

$(1 / 2) \quad 39-45$

Geiss, F.: see Boni, M.

$(1 / 2) \quad 83-86$

Goldstein, M., Year 2000

(6) $333-340$

Hämäläinen, P., Developing an executive information system: people dynamics

(5) $275-280$

Hassanaly, A.: see Dou, $\mathrm{H}$.

(3) $135-145$

Huismans, J.W.: see Sundén, A.

(1/2) 93- 99

Jørgensen, J.: see Tüchsen, F.

$(1 / 2) \quad 15-23$

0167-5265/91/\$03.50 @ 1991 - Elsevier Science Publishers B.V. 
Kahnert, A., on behalf of the Economic Commission for Europe (ECE), Experience obtained in ECE work on environment statistics relating to environmental health databases

$(1 / 2) \quad 87-91$

Kaldor, J., The use of cancer registries in identifying environmental risks

$(1 / 2) 127-131$

Kar, D.C. and A.M. Siddiqui, Bibliographic database RIZA: design and development using mini/micro CDS/ISIS Version 2.3

(5) $261-274$

Koenig, M.E.D., Information technology and perestroika

(5) $315-320$

La Tela, A.: see Dou, $\mathrm{H}$.

Lawrence, B., Database publishers' challenges for the future

(3) $135-145$

Leung, C.H.C., Architecture of an image database system

(5) 293-304

(6) $391-397$

MacColl, J.A., Library applications of a wide area network: promoting JANET to UK academic libraries

Matsumura, T., The Japanese information scene: Today and tomorrow

(3) $157-168$

(6) $351-361$

Matthew, G.K., The provision and use of data for the study of environmental health problems: developments in the UK

Matthies, M.: see Behling, G.

Matthies, M.: see Voigt, K.

$(1 / 2) \quad 25-38$

(4) $205-214$

(4) $215-222$

Maxon-Dadd, J., Refurbishing an elegant Victorian database-A view from DIALOG

Mücke, W.: see Voigt, K.

(6) $363 \cdots 369$

(4) $215-222$

News, Trends and Comments

(3) $191-202$

News, Trends and Comments

(5) $321-330$

Nkereuwem, E.E., Issues on the relationship between job satisfaction, job attitudes and work behaviour among the staff in academic libraries

(5) $281 \cdots-291$

Peare, C.W.D., Environmental statistics in the European Community

$(1 / 2) \quad 77-80$

Penning, W.: see Boni, M.

$(1 / 2) \quad 83-86$

Quoniam, L.: see Dou, H.

(3) $135-145$

Rowley, J.E., A comparison between free language and controlled language indexing and searching

Ryan, R.P. and B. Coalgate, Customer service and marketing at the Defense Technical Information Center

(3) $147-155$

(6) $371-379$

Savolainen, K.: see Tuomisto, J.

(4) $233-241$

Schock, U. and Ch. Weiske, Chemical data banks in Europe

$(1 / 2) 107-126$

Siddiqui, A.M.: see Kar, D.C.

Spuhler, Th., Information sources of health and environmental data: the Swiss example

(5) 261-274

Stern, R.M. and S. Tarkowski, The need for a unified European environmental health database

(4) $229-231$

Stern, R.M., Introduction

$(1 / 2) \quad 5-14$

Stern, R.M., Introduction

$(1 / 2) \quad 1-3$

(4) 203-204

Summary report: Consultation on environmental health information systems in the European Region

Sundén, A. and J.W. Huismans, The International Register of Potentially Toxic Chemicals (IRPTC): its databank and network partners

(4) $251-257$

$(1 / 2) \quad 93-99$ 
Tarkowski, S.: see Stern, R.M.

$(1 / 2) \quad 5-14$

Tüchsen, F. and E. Bach, in collaboration with O. Andersen and J. Jørgensen, The use of a national hospital register for hypothesis generation

$(1 / 2) \quad 15-23$

Tuomisto, J. and K. Savolainen, Background information for a European metadatabase on environment and health information sources: Finland

(4) $233-241$

Vaden, W.M.: see Coyne, J.G.

Voigt, K., J. Benz, M. Matthies and W. Mücke, Information system on environmental chemicals: databank of data sources for environmental chemicals

(6) $341-350$

(4) $215-222$

Wagner, B.O., Chemical databank and the evaluation of toxicity

$(1 / 2) 101-105$

Weiske, Ch.: see Schock, U.

$(1 / 2) 107-126$

Ydreborg, B., Questionnaire-based database on occupation and health status

$(1 / 2) \quad 47-51$

Zadka, P., Environment and health information systems: Israel

(4) $243-150$ 